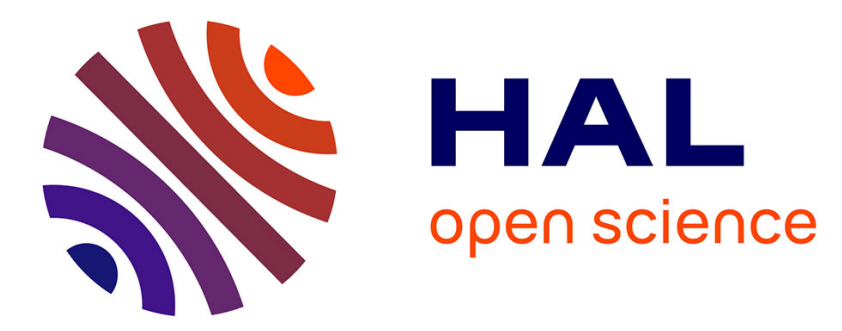

\title{
Impacts of earthworm species on soil acidification, Al fractions, and base cation release in a subtropical soil from China
}

Jialong Wu, Chi Zhang, Ling Xiao, Mikael Motelica-Heino, Zongling Ren, Ting Deng, Jun Dai

\section{To cite this version:}

Jialong Wu, Chi Zhang, Ling Xiao, Mikael Motelica-Heino, Zongling Ren, et al.. Impacts of earthworm species on soil acidification, Al fractions, and base cation release in a subtropical soil from China. Environmental Science and Pollution Research, 2020, 27, pp.33446-33457. 10.1007/s11356-019-050558. insu- 02106413

\section{HAL Id: insu-02106413 https://hal-insu.archives-ouvertes.fr/insu-02106413}

Submitted on 15 Feb 2021

HAL is a multi-disciplinary open access archive for the deposit and dissemination of scientific research documents, whether they are published or not. The documents may come from teaching and research institutions in France or abroad, or from public or private research centers.
L'archive ouverte pluridisciplinaire HAL, est destinée au dépôt et à la diffusion de documents scientifiques de niveau recherche, publiés ou non, émanant des établissements d'enseignement et de recherche français ou étrangers, des laboratoires publics ou privés. 


\title{
Impacts of earthworm species on soil acidification, Al fractions, and base cation release in a subtropical soil from China
}

\author{
Jialong Wu $\mathrm{W}^{1,2,3,4}$ \& Chi Zhang ${ }^{1,2,3,4}$ \& Ling Xiao ${ }^{1,2,3,4}$ \& Mikael Motelica-Heino ${ }^{5}$ \& Zongling Ren Ren $^{1,2,4}$ \& Ting Deng ${ }^{1,2,3,4}$ \& \\ Jun Dai $1,2,3,4$
}

\begin{abstract}
Soil-exchangeable aluminum $(\mathrm{Al})$ has toxic effects on living organisms in acidic soils. Earthworm presence and activity can alter soil $\mathrm{pH}$, which has a significant influence on $\mathrm{Al}$ toxicity. However, the effects of earthworms on soil Al toxicity and fractions are still largely unknown. This laboratory study focused on the effects of three earthworm species (endogeics Pontoscolex corethrurus and Amynthas robustus, anecis Amynthas aspergillum) on soil acidification, Al fraction distribution, and base cation release. Three native earthworm species and a soil (latosolic red soil) collected from a botanical garden in South China were incubated under laboratory conditions. After 40 days of incubation, six Al fractions in soil, namely exchangeable (AlEx), weakly organically bound $\left(\mathrm{Al}_{\mathrm{Orw}}\right)$, organically bound $\left(\mathrm{Al}_{\mathrm{Or}}\right)$, amorphous $\left(\mathrm{Al}_{\mathrm{Amo}}\right), \mathrm{Al}$ occluded in crystalline iron oxides $\left(\mathrm{Al}_{\mathrm{Oxi}}\right.$ ), and amorphous aluminosilicate and gibbsite ( $\mathrm{Al}_{\mathrm{Aag}}$ ) fractions, were extracted using a sequential procedure. Soil $\mathrm{pH}$; organic carbon; total nitrogen; total $\mathrm{Al}$ (AlTotal); exchangeable $\mathrm{K}, \mathrm{Na}, \mathrm{Ca}, \mathrm{Mg}$ contents; and $\mathrm{CEC}$ were determined as well. Compared to control soil, $\mathrm{pH}$ values increased by $0.79,0.41$, and 0.57 units in casts in the presence of P. corethrurus, A. robustus, and A. aspergillum, and $0.70,0.32$, and 0.50 units in non-ingested soil, respectively. Compared to control soil, the $61.7 \%, 30.7 \%$, and $36.1 \%$ of $\mathrm{Al}_{\mathrm{Ex}}$ contents in casts and $68.5 \%, 25.9 \%$, and $39.0 \%$ of $\mathrm{AlEx}$ in non-ingested soil significantly decreased with the addition of P. corethrurus, A. robustus, and A. aspergillum, respectively. Moreover, compared to control soil, the $78.7 \%, 37.7 \%$, and $40.1 \%$ of exchangeable $\mathrm{Ca}^{2+}$ and $12.3 \%, 24.7 \%$, and $26.8 \%$ of exchangeable $\mathrm{Mg}^{2+}$ contents in casts significantly increased with the presence of P. corethrurus, A. robustus, and A. aspergillum, respectively. Soil treated with P. corethrurus had higher soil $\mathrm{pH}$ values, exchangeable $\mathrm{Ca}^{2+}$ contents, and lower AlEx than those with A. robustus and A. aspergillum. Results of principal component analyses showed that $\mathrm{P}$. corethrurus, A. robustus, and A. aspergillum casts and non-ingested soil differ for soil $\mathrm{pH}, \mathrm{Al}$ fractions, and exchangeable base cations release. These results indicate that earthworms, especially P. corethrurus, can reduce soil $\mathrm{Al}$ toxicity, increase soil $\mathrm{pH}$, and affect the release of exchangeable base cations.
\end{abstract}

Highlights

-P. corethrurus decreased $61.7 \%$ exchangeable $\mathrm{Al}$ content

significantly in cast compared to control soil.

- P. corethrurus was more effective to reduce soil acidification than

A. robustus and A. aspergillum.

- Casts had higher exchangeable $\mathrm{Ca}^{2+}, \mathrm{Mg}^{2+}, \mathrm{K}^{+}, \mathrm{CEC}, \mathrm{TN}$, and

SOC than non-ingested soil for the three earthworms.

Responsible editor: Zhihong Xu

* Chi Zhang

zhangchi121@163.com

* Jun Dai

jundai@scau.edu.cn

1 College of Natural Resources and Environment, South China Agricultural University, 483 Wushan Road, Tianhe District, Guangzhou 510642, China

2 Key Laboratory of Arable Land Conservation in South China, Ministry of Agriculture People's Republic of China, Guangzhou 510642, China
3

Key Laboratory of the Ministry of Land and Resources for Construction Land Transformation, Guangzhou 510642, China

4 Guangdong Province Key Laboratory of Land Use and Consolidation, Guangzhou 510140, China

5

Université d'Orléans, CNRS/INSU Institut des Sciences de la Terre d'Orléans, UMR 7327, Campus Géosciences, 1A rue de la Férollerie, 41071 Orleans, France 
Keywords Earthworms ${ }^{`}$ Aluminum fractions ${ }^{\circ}$ Soil $\mathrm{pH}^{\star}$ Exchangeable base cations ${ }^{\circ}$ Latosolic red soil

\section{Introduction}

Soil acidification is a global ecological and environmental issue that has however received little attention until now (Guo et al. 2010). It has naturally occurred across tropical and subtropical regions (Hodson and Donner 2013) and is strongly influenced by anthropogenic atmospheric acid depo-sition (Qiao et al. 2015; Zhao et al. 2009). It is well known that acid soils are commonly associated with $\mathrm{Al}$ toxicity, which is terribly deleterious to various soil organisms. Kunito et al. (2016) reported that high levels of exchangeable $\mathrm{Al}$ can be expected to increase stresses on organisms via Al toxicity; Zhang et al. (2013) found that the critical value of $\mathrm{Al}$ in soil for earthworm Eisenia fetida was $50 \mathrm{mg} \mathrm{kg}^{-1}$; Gestel and Hoogerwerf (2001) reported that $\mathrm{AlCl}_{3}$ was more toxic to earthworm Eisenia Andrei compared to $\mathrm{Al}_{2} \mathrm{O}_{3}$ and $\mathrm{Al}_{2}\left(\mathrm{SO}_{4}\right)_{3}$, with $\mathrm{LC}_{50}$ value of $316 \mathrm{mg} \mathrm{kg}^{-1}$ dry artificial soil at a $\mathrm{pH}_{\mathrm{KCl}}$ of 3.5 .

$\mathrm{Al}$ fractions determine its toxicity besides its total concentration (Kubová et al. 2005; Ščančar and Milačič 2006) and are also closely related to soil $\mathrm{pH}$ (Xu 2012). When soil pH is below 5.0, exchangeable $\mathrm{Al}$ mainly includes $\mathrm{Al}^{3+}, \mathrm{AlOH}^{2+}$, $\mathrm{Al}(\mathrm{OH})_{2}{ }^{+}, \mathrm{Al}(\mathrm{OH})_{3}$, and $\mathrm{Al}(\mathrm{OH})_{4}$ species $\mathrm{Al}^{3+}$ being the most toxic (Baquy et al. 2018). Most of $\mathrm{Al}$ in soil is bound to organic matter in the form of polymers and monomers that are of low toxicity (Buodot et al. 1994). In general, $\mathrm{Al}$ can be divided into several fractions in soils such as $\mathrm{Al}_{\mathrm{Ex}}$ (exchangeable), Al Orw (weakly organically bound), $\mathrm{Al}_{\text {Or }}$ (organically bound), $\mathrm{Al}_{\mathrm{Amo}}$ (amorphous), $\mathrm{Al}_{\mathrm{Oxi}}$ (occluded in crystal-line iron oxides), and $\mathrm{Al}_{\mathrm{Aag}}$ (occluded in amorphous alumino-silicate and gibbsite) (Larssen et al. 1999). Hagvall et al. (2015) investigated the effects of organic matter on the frac-tions of Al in soils. Evans and Jacobs (2016) evaluated the seasonal changes in $\mathrm{Al}$ fractions in soil. However, no infor-mation exists regarding the impacts of soil fauna on $\mathrm{Al}$ speci-ation and toxicity recently in tropical soils.

Earthworms are an essential part of soil fauna in most soils (Blouin et al. 2013), and they play an important role in the transformations of soil chemical elements such as $\mathrm{Cd}, \mathrm{Cu}, \mathrm{Pb}$, and $\mathrm{Zn}$, and so on (Richardson et al. 2018; Zhang et al. 2016). Basker et al. (1994) demonstrated that soil ingestion by earthworm A. caliginosa and $\mathrm{L}$. rubellus increased exchangeable $\mathrm{K}$ content in Raumai soil. Previous studies have addressed the effects of earthworms on soil metal (loid) $(\mathrm{Cd}, \mathrm{Cu}, \mathrm{Zn}$, and $\mathrm{As}$ ) mobility, fractions, and availability through soil $\mathrm{pH}$ change (Sizmur and Hodson 2009) and the degradation and redistribution of organic matter (Tica et al. 2013; Sizmur et al. 2011; Zhang et al. 2009). However, far less attention has been paid to the impact that earthworms have on soil $\mathrm{Al}$ in terms of its toxicity and fractions. Endogeic species such as Pontoscolex corethrurus (Müller 1857) and Amynthas robustus (Perrier 1872) and anecics species Amynthas aspergillum (Perrier 1872) are the most common earthworms in south China (Huang et al. 2015; Lin et al. 2012). However, there is no data on how the ecology of these earthworm species affects soil $\mathrm{Al}$ fractions and toxicity in subtropical soils.

Therefore, in the present study, the objectives were to in-vestigate the effects of different earthworm species such as Pontoscolex corethrurus, Amynthas robustus, and Amynthas aspergillum on soil acidification, Al speciation and exchange-able base cation release and also evaluate the impacts of earth-worm presence and activity on reducing soil acidity and changing $\mathrm{Al}$ fractions.

\section{Materials and methods}

\section{Soil and biological preparation}

Natural uncontaminated soil was collected from surface horizon $(0-10 \mathrm{~cm})$ at a botanical garden in Guangdong province, South China $\left(23^{\circ} 9^{\prime} 33^{\prime \prime} \mathrm{N}\right.$ and $\left.113^{\circ} 21^{\prime} 22^{\prime \prime} \mathrm{E}\right)$. It was air-dried and then sieved at $3 \mathrm{~mm}$. pH value, fine texture, and contents of organic carbon and total nitrogen were determined in soil (Table 1).

All earthworms (Pontoscolex corethrurus, Amynthas robustus, and Amynthas aspergillum) were hand-sorted in the field from the same location. Mature individuals with developed clitellum were selected to apply in the laboratory tests. To ensure the soil contained a large proportion of earthworm casts, a relatively large number of earthworms were added to a comparatively small volume of soil and a short treatment time was selected (Zhang et al. 2000; Zhang et al. 2016). The average fresh weights of $P$. corethrurus were 0.29 $\mathrm{g}$ fresh weight (ranging from 0.27 to $0.31 \mathrm{~g}$ ind $^{-1}$ ), and 41 individuals were added to $0.5 \mathrm{~kg}$ soil. A. robustus were $2.91 \mathrm{~g}$ fresh weight on average (ranging from 2.10 to $3.17 \mathrm{~g}$ ind $^{-1}$ ), and 4 worms were added to $0.5 \mathrm{~kg}$ soil. A. aspergillum were $2.34 \mathrm{~g}$ fresh weight (ranging from 1.10 to $4.07 \mathrm{~g}$ ind $^{-1}$ ) on average, and 6 individuals were added to $0.5 \mathrm{~kg}$ soil.

\section{Experimental design}

Half a kilogram of soil was placed in $1.5 \mathrm{~L}$ plastic plots $(9 \mathrm{~cm}$ $\times 12 \mathrm{~cm} \times 13 \mathrm{~cm})$ allocated to four different treatments:

1. CS: control soil without earthworms

2. PS: soil inoculated with $12.0 \pm 0.0 \mathrm{~g}$ fresh weight of P. corethrurus

3. RS: soil inoculated with $12.5 \pm 0.1 \mathrm{~g}$ fresh weight of A. robustus 
Table.1 Main physicochemical characteristics and Al contents of soil samples (mean \pm S.E., $\mathrm{n}=3$ )

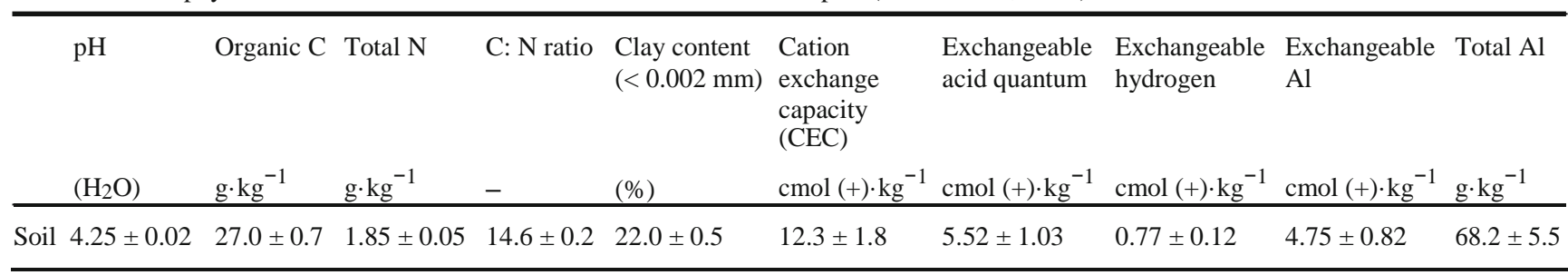

4. AS: soil inoculated with $12.1 \pm 0.0 \mathrm{~g}$ fresh weight of A. aspergillum

Each treatment with five replicates was incubated for 40 days in the laboratory at a temperature of $25{ }^{\circ} \mathrm{C}$ and moisture was adjusted by weight at field capacity every 2 days. Organic matter was not added during the whole culture period so as not to influence soil properties. In the medium term of the incubation, surface casts were collected. After 40 days of incubation, both internal and surface casts were collected according to the method of Zhang et al. (2016). After being dried in an air-circulating room, surface casts and internal casts were mixed together and used as the casts in this study. The casts and non-ingested soil were weighed to estimate total cast pro-duction (Wen et al. 2006).

\section{Analytical determinations}

\section{Earthworm responses}

Surviving earthworms were collected, counted, and weighed at the beginning, after 20 days and at the end of the culture period. Ingestion rate (I in $\mathrm{g}$ dry soil ingested daily per $\mathrm{g}$ fresh weight earthworm biomass) was calculated as follows:

\section{I $\quad \frac{\partial \mathrm{C}=\mathrm{dP}}{1 / 4 / 2 \mathrm{~W} D \mathrm{p} W(0 \mathrm{P}=2} \quad 100 \%$ \\ $1 / 4{ }^{1} / 2{ }^{\partial} W_{0} p ~ W_{40} P=2$}

where $\mathrm{C}$ is the total cast production (surface cast + internal cast) in $\mathrm{g}$ dry weight, $\mathrm{d}$ is culture duration in days, and $\mathrm{W}_{0}$ and $\mathrm{W}_{40}$ is the biomass of earthworms at the beginning and end of the culture period (Zhang et al. 2016).

\section{Soil and casts analyses}

Soil $\mathrm{pH}$ value was determined in water suspension [1: 2.5 (w/ v) soil/distilled water ratio] by a Sartorius $\mathrm{PB}-10 \mathrm{pH}$ meter. Exchangeable acid quantum and hydrogen were measured according to $\mathrm{KCl}$ exchange-neutralization titration method (SSIR 2004). Cation exchange capacity (CEC) was determined by the method of ammonium acetate saturation $\left(\mathrm{CH}_{3} \mathrm{COONH}_{4}, 1 \mathrm{~mol} \mathrm{~L}^{-1}, \mathrm{pH} 7.0\right)$. Soil was digested by hot $\mathrm{HF}, \mathrm{HNO}_{3}, \mathrm{HClO}_{4}$, and $\mathrm{H}_{2} \mathrm{O}_{2}$ mixture and analyzed by inductively coupled plasma optical emission spectrometry
(ICP-OES) (Varian 710-ES) in order to determine total Al concentration (Kubová et al. 2005). The optimized six-step sequential extraction scheme was applied according to the method of Larssen et al. (1999), and Al concentrations in the extracts were also determined by ICP-OES (Varian 710-ES) (Table 2). Soil-exchangeable $\mathrm{Ca}, \mathrm{Mg}, \mathrm{K}$, and $\mathrm{Na}$ were extract-ed with $1 \mathrm{~mol} \mathrm{~L}^{-1} \mathrm{CH}_{3} \mathrm{COONH}_{4}(\mathrm{pH} 7.0)$ and then measured by atomic absorption spectrometry as previously described (Moro et al. 2014). All subsequent data were expressed on dry weight bases.

\section{Analysis of earthworms}

Earthworms were placed in Petri dishes with one filter paper and a few drops of distilled water to keep them moist. They were kept at $25^{\circ} \mathrm{C}$ for 7 days, and filter papers were changed daily to allow complete evacuation of the gut contents. Earthworms were killed in liquid nitrogen and then oven-dried at $100{ }^{\circ} \mathrm{C}$ for $24 \mathrm{~h}$. Dry earthworms were crushed $(<0.2 \mathrm{~mm})$ and digested as follows: $0.2 \mathrm{~g}$ of sample was mixed with $8 \mathrm{ml}$ concentrated $\mathrm{HNO}_{3}$ and $2 \mathrm{ml}$ concentrated $\mathrm{HClO}_{4}$ for $12 \mathrm{~h}$, heated progressively up to $250{ }^{\circ} \mathrm{C}$ with electric heating plate digestion for $2 \mathrm{~h}$. After cooling at ambient tem-perature, the solution was filled up to $50 \mathrm{ml}$ with ultra-pure distilled water (Dai et al. 2004). Metal contents in earthworms were determined by ICPOES (Varian 710-ES). Biota-to-soil accumulation factors (BSAF) of the metals in the earthworms were calculated by the following formula: $\mathrm{BSAF}=$ metal con-tent in earthworm / total metal content in soil (Cortet et al. 1999).

\section{Statistical analysis}

All data were analyzed using the software SPSS version 23.0 (SPSS Inc., Chicago, IL) and R version 3.0.2 (ade 4 library) (R Development Core Team 2007; Thioulouse et al. 1997), re-spectively. Differences between the means were evaluated using a one-way ANOVA which was tested by Duncan's test. $\mathrm{p}<0.05$ was considered as statistically significant. Results were expressed as mean \pm standard error. Principal component analysis (PCA) was performed using the software R (ade 4 library), coupled with a Monte Carlo permutation test that allowed to test for multivariate differences between treatments. 
Table 2 Experimental conditions in the optimized six-step sequential extraction scheme

\begin{tabular}{|c|c|c|c|}
\hline Step & Abbreviation & Fraction & Chemical reagents, analytical conditions, and references \\
\hline 1 & $\mathrm{Al}_{\mathrm{Ex}}$ & Exchangeable & $0.1 \mathrm{~mol} \cdot \mathrm{L}^{-1} \mathrm{BaCl}_{2}(\mathrm{w} / \mathrm{v}=1 / 10)$ for $2 \mathrm{~h}$, extract twice, rinsing by redistilled $\mathrm{H}_{2} \mathrm{O}$ \\
\hline 2 & Al $_{\text {Orw }}$ & Weakly organically bound $^{\mathrm{a}}$ & $0.5 \mathrm{~mol} \mathrm{~L}^{-1} \mathrm{CuCl}_{2}(\mathrm{w} / \mathrm{v}=1 / 10)$ for $2 \mathrm{~h}$, extract twice, rinsing by redistilled $\mathrm{H}_{2} \mathrm{O}$ \\
\hline 3 & $\mathrm{Al}_{\text {Or }}$ & Organically bound & $\begin{array}{l}0.1 \mathrm{~mol} \mathrm{~L}^{-1} \mathrm{Na}_{4} \mathrm{P}_{2} \mathrm{O}_{7}(\mathrm{pH} 10)(\mathrm{w} / \mathrm{v}=1 / 40) \text { for } 16 \mathrm{~h} \text {, } \\
\quad \text { extract twice, rinsing by } 1 \mathrm{~mol} \mathrm{~L}^{-1} \mathrm{Na}_{2} \mathrm{SO}_{4}\end{array}$ \\
\hline 4 & Al ${ }_{\text {Amo }}$ & Amorphous & $\begin{array}{l}\mathrm{NH}_{4} \text { oxalate }\left(0.2 \mathrm{~mol} \mathrm{~L}^{-1} \text { at } \mathrm{pH} 3\right)(\mathrm{w} / \mathrm{v}=1 / 40) \text { for } 4 \mathrm{~h} \text { in dark, } \\
\quad \text { rinsing by redistilled } \mathrm{H}_{2} \mathrm{O}\end{array}$ \\
\hline 5 & Al & Occluded in crystalline iron oxides & Citrate dithionite for $15 \mathrm{~min}, 80^{\circ} \mathrm{C}(\mathrm{w} / \mathrm{v}=1 / 40)$, rinsing by $1 \mathrm{~mol} \mathrm{~L}^{-1} \mathrm{NaCl}$ \\
\hline 6 & Al $_{\text {Aag }}$ & Amorphous aluminosilicate and gibbsite & Boiling $0.1 \mathrm{~mol} \cdot \mathrm{L}^{-1} \mathrm{NaOH}$ for $2.5 \mathrm{~min}(\mathrm{w} / \mathrm{v}=1 / 500)$. \\
\hline- & $\begin{array}{l}{ }^{\mathrm{Al}}{ }_{\mathrm{Min}} \\
\mathrm{Al}\end{array}$ & Occluded in layered aluminosilicate & $\mathrm{Al}_{\text {total }}-\sum \mathrm{Al}$ \\
\hline & $\mathrm{Al}_{\text {Total }}$ & Total Al & decomnosed hy hot $\mathrm{HE}_{\mathrm{HNO}} \mathrm{HNClO}_{4}$ and $\mathrm{H}_{2} \mathrm{O}_{2}$ mixture (Kuhová et al 2005 ) \\
\hline
\end{tabular}

aExtraction with $0.5 \mathrm{~mol} \mathrm{~L}^{-1} \mathrm{CuCl}_{2}$ is considered organo-Al complexes of low to medium stability (Álvarez et al. 2012)

$\mathrm{bAl}$ is occluded in layered silicates in most of soils and cannot be extracted by above chemical reagents, $\mathrm{Al}$ Min $=\mathrm{Al}$ Total $-\sum \mathrm{Al}, \sum \mathrm{Al}=\mathrm{Al}$ Ex $+\mathrm{Al}$ Orw + $\mathrm{Al}$ Or $+\mathrm{Al}_{\mathrm{Amo}}+\mathrm{Al}_{\text {Oxi }}+\mathrm{Al}_{\text {Aag }}($ Shao et al. 1998)

\section{Results}

\section{Earthworm response to soil}

Earthworm survival percentage, biomass, and weight loss rate for the different treatments are shown in Table. 3. At the end of the experiment, P. corethrurus had the lowest survival percentage $(79.1 \%)$ and biomass $(8.89 \mathrm{~g})$ but the highest weight loss rate $(25.98 \%)$ com-pared to other earthworm species. In contrast to $\mathrm{P}$. corethrurus, A. robustus had the highest survival per-centage (97.1\%), biomass (12.5 g), and lowest weight 1 o s s r a t e ( -0.12 $\%$ ). Th e w e ig h t lo s s r a t e o f P. corethrurus was significantly higher than that of A. robustus $(\mathrm{p}<0.05)$. However, there was no signifi-c a $\mathrm{nt}$ d if f e r e n c e in w eightlossratebetween

P. corethrurus and A. aspergillum. The survival percentage, biomass, and weight loss rate of A. aspergillum were allbetweenthos e of P. core thrurusan d A. robustus, respectively.
Surface cast production of P. corethrurus $\left(67.9 \mathrm{~g} \mathrm{~kg}^{-1}\right)$ and A. aspergillum $\left(53.4 \mathrm{~g} \mathrm{~kg}^{-1}\right)$ were significantly higher than that of A. robustus $\left(67.0 \mathrm{~g} \mathrm{~kg}^{-1}\right)(\mathrm{p}<0.05$, Fig. Error! Reference source not found.a). Inter cast productions of the three earthworms were significantly different and ranked as P. corethrurus $>$ A. robustus $>$ A. aspergillum, with the mean values of $296.0,224.0$, and $61.4 \mathrm{~g} \cdot \mathrm{kg}^{-1}$, respectively $(\mathrm{p}<$ 0.05 , Fig. 1b). The amounts of the inter cast of P. corethrurus and A. robustus were 4.4- and 4.2-fold higher than the surface cast ( $\mathrm{p} 0.05$ ), respectively. Generally, P. corethrurus and A. robustus produced significantly greater amounts of total casts than A. aspergillum ( $<<0.05$, Fig. 1c). Soil ingestion rates were 1.99- and 0.94-fold higher, respec-tively, for $\mathrm{P}$. corethrurus and A. robustus $(\mathrm{p}<0.05)$ than for A. aspergillum (Fig. 1d). Bioaccumulation values of $\mathrm{Al}$ in earthworms assessed by BSAF were ranked as A. robustus >

P. corethrurus $>A$. aspergillum, with the mean values of $0.087,0.158$, and 0.002 , respectively $(\mathrm{p}<0.05)$. BSAFs were 42.3- and 77.8-fold higher, respectively, for P. corethrurus and A. robustus $(\mathrm{p}<0.05)$ than A. aspergillum (Fig. 1e).

Table 3 Variations of survival percentage, biomass, and weight loss rate of different earthworm species during the incubation period (mean \pm S.E., $\mathrm{n}=5$ )

Treatments Incubation days

\begin{tabular}{|c|c|c|c|c|c|c|c|}
\hline & \multicolumn{2}{|l|}{$0 \mathrm{~d}$} & \multicolumn{2}{|l|}{$20 \mathrm{~d}$} & \multicolumn{3}{|l|}{$40 \mathrm{~d}$} \\
\hline & Survival rate $(\%)$ & Biomass (g) & Survival rate $(\%)$ & Biomass (g) & Survival rate $(\%)$ & Biomass (g) & Weight loss rate $(\%)$ \\
\hline PS & $100 \pm 0 \mathrm{a}$ & $12.0 \pm 0.0 \mathrm{a}$ & $87.5 \pm 5.0 \mathrm{~b}$ & $11.5 \pm 0.6 \mathrm{a}$ & $79.1 \pm 2.2 b$ & $8.89 \pm 0.5 b$ & $26.0 \pm 4.5 \mathrm{~A}$ \\
\hline $\mathrm{RS}$ & $100 \pm 0 \mathrm{a}$ & $12.5 \pm 0.1 b$ & $97.1 \pm 2.9 \mathrm{a}$ & $14.9 \pm 0.5 \mathrm{a}$ & $97.1 \pm 2.9 \mathrm{a}$ & $12.5 \pm 0.3 b$ & $-0.12 \pm 2.8 \mathrm{~B}$ \\
\hline AS & $100 \pm 0 \mathrm{a}$ & $12.1 \pm 0.0 \mathrm{ab}$ & $97.8 \pm 2.2 \mathrm{a}$ & $13.4 \pm 0.7 \mathrm{a}$ & $85.8 \pm 4.2 b$ & $10.5 \pm 0.8 b$ & $13.4 \pm 6.3 \mathrm{AB}$ \\
\hline
\end{tabular}

The different lowercase letters relate to the different levels of Duncan in one-way ANOVA analysis at different incubation days $(\alpha=5 \%)$. The different capital letters relate to the different levels of Duncan in One-way ANOVA analysis of treatments in weight loss rate as follows $(\alpha=5 \%)$

PS soil + P. corethrurus, RS soil + A. robustus, AS soil + A. aspergillum 
Fig. 1 Earthworm cast production, ingestion rate, and BSAF in different treatments. PS: soil + P. corethrurus; RS: soil + A. robustus; AS: soil + A. aspergillum. The different lowercase letters relate to the different levels of Duncan in one-way ANOVA analysis of treat-ments $(\mathrm{n}=5, \alpha=5 \%)$
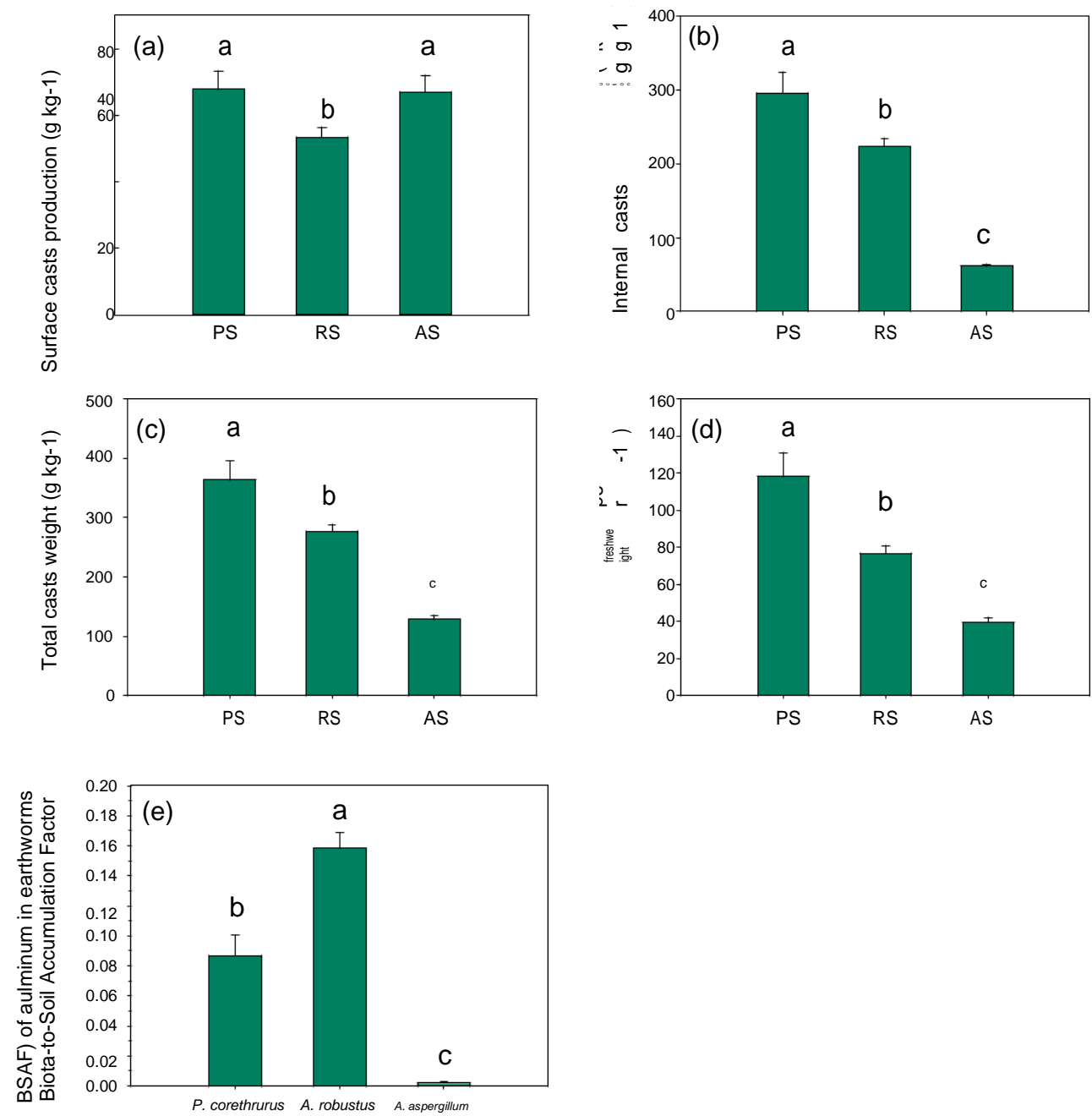

\section{Variations of soil $\mathrm{pH}$ in treatments}

The addition of the three species of earthworm significantly increased $\mathrm{pH}$ values in casts and non-ingested soil $(\mathrm{p}<0.05$, Fig. 2). Compared to control soil, P. corethrurus, A. robustus, and $\mathrm{A}$. aspergillum increased $\mathrm{pH}$ values by $0.79,0.41$, and 0.57 units respectively in casts. Similarly, $\mathrm{pH}$ values in noningested soil were $0.70,0.32$, and 0.50 higher, respectively, with P. corethrurus, A. robustus, and A. aspergillum than for the control soil. Moreover, all earthworm casts had significantly higher $\mathrm{pH}$ values than the corresponding non-ingested soil (P. corethrurus: $\mathrm{p}<0.05$; A. robustus: $\mathrm{p}<0.05$; A. aspergillum: $\mathrm{p}<0.01$, Fig. 2), respectively.

\section{Variation of Al fractions and distribution in treatments}

Al fractions assessed by chemical extractions varied significantly among treatments in casts as well as noningested soil (Table 4). Compared to control, 61.7\% (130 $\left.\mathrm{mg} \mathrm{kg}^{-1}\right), 30.7 \%$ (64.0 $\mathrm{mg} \mathrm{kg}^{-1}$ ), and $36.1 \%$

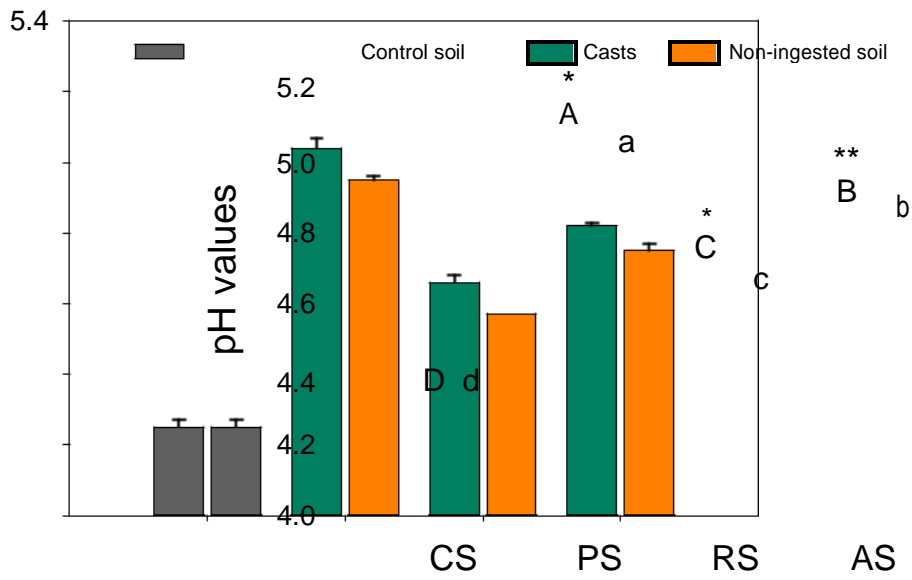

Fig. 2 Soil $\mathrm{pH}$ affected by earthworm in different treatments (CS: control soil; PS: soil + P. corethrurus; RS: soil + A. robustus; AS: soil + A. aspergillum). The different capital letters relate to the different levels of Duncan in one-way ANOVA analysis of treatments in casts group as follows $(\alpha=5 \%)$. The different lowercase letters relate to the different levels of Duncan in one-way ANOVA analysis of treatments in non-ingested soil group as follows ( $\mathrm{n}=5, \alpha=5 \%)$. Significant differences between casts and the non-ingested soil group of T test are note by ***p $<0.001 ;{ }^{* *} \mathrm{p}<0.01$; $\mathrm{p}<<0.05 ; \mathrm{ns} \mathrm{p}>0.05$ 
(76.0 m kg kg ${ }^{-1}$ ) decreases were observed in AlEx contents in the casts of PS, RS, and AS treatments, respectively, and $68.5 \%\left(144 \mathrm{mg} \mathrm{kg}^{-1}\right), 25.9 \%\left(54.0 \mathrm{mg} \mathrm{kg}^{-1}\right)$, and $39.0 \%$ $\left(82.0 \mathrm{~m} \mathrm{~kg}^{-1}\right)$ decreases of that found in non-ingested soil as well. In the meantime, differences of $\mathrm{Al}_{\mathrm{Ex}}$ contents between casts and non-ingested soil were earthworm species dependent and ranked as follow: AlEx contents in non-ingested soil with A. robustus >

A. robustus casts $>$ P. corethrurus casts $>$ non-ingested soil with P. corethrurus $(p<0.05)$; however, no significant difference was found between A. aspergillum casts and non-ingested soil ( $p>0.05)$. In the presence of earthworms, AlOrw fractions in casts and non-ingested soil varied notably. Compared to control soil, AlOrw contents in non-ingested soil significantly decreased by $21.4 \%$,

$7.64 \%$, and $6.18 \%$ due to the activities of

P. corethrurus, A. robustus, and A. aspergillum, respectively. Higher Alorw contents were found in casts compared to non-ingested soil (P. corethrurus: $\mathrm{p}<0.05$; A. robustus: $\mathrm{p}<0.01$; A. aspergillum: $\mathrm{p}<0.01$, Table 4). Earthworm addition could increase Alor contents not only in casts but also in non-ingested soil. In comparison to control, AlOr contents in casts increased by 0.74-, 0.78-, and 0.48 -fold, respectively, in casts of P. corethrurus and A. robustus and A. aspergillum ( $p<0.05)$. Alor contents in no n - ingestedsoilaffectedby A. robustusa $\mathrm{n} \mathrm{d} \mathrm{A.} \mathrm{aspergillum} \mathrm{were} \mathrm{significantly} \mathrm{higher} \mathrm{than} \mathrm{control} \mathrm{soil}$ $(p<0.05)$. Compared with non-ingested soil, the ingestion by $\mathrm{P}$. corethrurus and A. robustus significantly increased the $\mathrm{Al}$ Or in casts (P. corethrurus: $\mathrm{p}<0.01$; A. robustus:

$\mathrm{p}<0.05$, respectively, Table 4). $\mathrm{Al}_{\mathrm{Amo}}$ fractions in casts and non-ingested soil were influenced by the activities of the different earthworm species. Compared to control soil, $\mathrm{Al}_{\mathrm{Amo}}$ contents in casts generally increased significantly
( $\mathrm{p}<0.05)$. However $\mathrm{Al}_{\mathrm{Amo}}$ contents in non-ingested soil significantly decreased by $30.2 \%, 15.2 \%$, and $20.6 \%$, for $\mathrm{P}$. corethrurus and A. robustus and A. aspergillum ( $\mathrm{p}<$ 0.05), respectively. In addition, $\mathrm{Al}_{\mathrm{Amo}}$ contents in casts were significantly higher than for non-ingested soil (P. c o re thrurus: $\mathrm{p}<0.01 ;$ A . robust u s: $\mathrm{p}<0.05$; A. aspergillum: $p<0.01$, Table 4). Thus, earthworm addition could decrease Aloxi contents. Aloxi contents were significantlylowerincast swithadditio $\mathrm{n}$ o f P. corethrurus and A. robustus than for control soil ( $\mathrm{p}$ $<0.05$ ). Aloxi contents were $44.0 \%, 7.46 \%$, and $20.0 \% 1$ owerinnon-ingested soiltreated w ith P. corethrurus, A. robustus, and A. aspergillum, respectively, than control. It was also noted that Aloxi contents of the other two earthworms, and in general, Aloxi contents in casts, were higher than that in non-ingested soil ( $\mathrm{p}$ $<0.001)$. The presence of earthworms decreased $\mathrm{Al}_{\mathrm{Aag}}$ contents, especially in A. aspergillum and P. corethrurus casts and non-ingested soil. Earthworm activities increased AlMin contents, especially in A. aspergillum casts and non-ingested soil and in P. corethrurus non-ingested soil $(\mathrm{p}<0.05)$. There was no significant difference between $\mathrm{Al}_{\mathrm{Aag}}$ contents of casts and non-ingested soil for all earthworms, so as for AlMin (Table 4).

Average proportions of seven fractions in total contents varied notably among treatments (Fig. 3a, b). AlEx fractions in casts and non-ingested soil were $0.10-0.23 \%$, which were lower than control $(0.31 \%)$, especially for P. corethrurus, indicating that three earthworm activities could decrease the exchangeable $\mathrm{Al}$ contents. There were 1.52--1.78-fold increases of Alor contents in three casts $\mathrm{c}$ o m pared tocontrol. Thenon-ingested soi 1 of A. a spergillu m hadthehighest A 1 Or co $\mathrm{ntents}\left(785.21 \mathrm{mg} \mathrm{kg}^{-1}\right)$ of the three earthworms.

Table $4 \mathrm{Al}$ fractions and contents in soil (casts and non-ingested soils) (mean \pm S.E., $\mathrm{n}=5$ )

\begin{tabular}{|c|c|c|c|c|c|c|c|c|}
\hline \multirow[t]{2}{*}{ Treatments } & & \multicolumn{7}{|c|}{ Aluminum fractions } \\
\hline & & $\begin{array}{l}\text { Al } \\
\left(\mathrm{Al} \mathrm{mg} \cdot \mathrm{kg}^{-1}\right)\end{array}$ & $\mathrm{Al}_{\text {Orw }}$ & $\mathrm{Al}_{\text {Or }}$ & $\begin{array}{l}\mathrm{Al}_{\mathrm{Amo}} \\
\left(\mathrm{Al} \mathrm{g} \cdot \mathrm{kg}^{-1}\right) \\
\end{array}$ & $\mathrm{Al}_{\text {Oxi }}$ & $\mathrm{AI}_{\mathrm{Aag}}$ & $\mathrm{AI}_{\text {Min }}$ \\
\hline \multirow[t]{3}{*}{ Casts } & PS & $80.5 \pm 6.7 C^{*}$ & $271 \pm 16 \mathrm{~A}^{*}$ & $627 \pm 43 \mathrm{~A}^{* *}$ & $1.32 \pm 0.07 \mathrm{~A} * *$ & $0.69 \pm 0.01 \mathrm{AB} * * *$ & $10.9 \pm 0.5 \mathrm{~B} \mathrm{~ns}$ & $54.4 \pm 0.5 \mathrm{AB} \mathrm{ns}$ \\
\hline & $\mathrm{RS}$ & $146 \pm 3 B$ & $267 \pm 12 \mathrm{~A} * *$ & $634 \pm 65 A^{*}$ & $1.38 \pm 0.08 \mathrm{~A} *$ & $0.67 \pm 0.02 \mathrm{~B} \mathrm{~ns}$ & $11.2 \pm 1.4 \mathrm{AB} n s$ & $54.0 \pm 1.4 \mathrm{AB} \mathrm{ns}$ \\
\hline & AS & $134 \pm 7 \mathrm{~B} \mathrm{~ns}$ & $290 \pm 2 \mathrm{~A}^{* *}$ & $567 \pm 73 \mathrm{~A}$ & $1.47 \pm 0.04 \mathrm{~A}^{* *}$ & $0.61 \pm 0.01 \mathrm{C} \mathrm{ns}$ & $9.56 \pm 0.79 \mathrm{~B} \mathrm{~ns}$ & $55.6 \pm 0.8 \mathrm{~A} \mathrm{~ns}$ \\
\hline \multirow[t]{3}{*}{ Non-ingested soil } & PS & $66.2 \pm 3.2 \mathrm{~d}$ & $198 \pm 3 c$ & $275 \pm 22 b c$ & $0.90 \pm 0.03 c$ & $0.50 \pm 0.02 \mathrm{c}$ & $10.2 \pm 0.3 b$ & $56.1 \pm 0.3 a$ \\
\hline & $\mathrm{RS}$ & $156 \pm 3 b^{*}$ & $232 \pm 8 b$ & $350 \pm 17 b$ & $1.12 \pm 0.03 b$ & $0.67 \pm 0.01 \mathrm{a}$ & $12.6 \pm 0.6 \mathrm{a}$ & $53.2 \pm 0.6 b$ \\
\hline & AS & $128 \pm 14 c$ & $236 \pm 7 b$ & $785 \pm 66 \mathrm{a} n s$ & $1.07 \pm 0.04 b$ & $0.60 \pm 0.02 b$ & $9.46 \pm 0.41 b$ & $56.0 \pm 0.4 a$ \\
\hline Control & $\mathrm{CS}$ & $210 \pm 2 \mathrm{Aa}$ & $251 \pm 17 \mathrm{Aa}$ & $228 \pm 16 \mathrm{Bc}$ & $1.29 \pm 0.03 \mathrm{Aa}$ & $0.72 \pm 0.02 \mathrm{Aa}$ & $14.0 \pm 1.0 \mathrm{Aa}$ & $51.6 \pm 2.0 \mathrm{Bb}$ \\
\hline
\end{tabular}

The content of total $\mathrm{Al}$ in soil is $68.2 \pm 5.5 \mathrm{~g} \mathrm{~kg}^{-1}$. The different capital letters relate to the different levels of Duncan in one-way ANOVA analysis of casts of treatments in cast group as follows $(\alpha=5 \%)$. The different lowercase letters relate to the different levels of Duncan in oneway ANOVA analysis of treatments in non-ingested soil group as follows $(\alpha=5 \%)$

CS control soil, PS soil + P. corethrurus, RS soil + A. robustus, AS soil + A. aspergillum, ns $p>0.05$

Significant differences between the casts and the non-ingested soil group of T test are noted by $* * * \mathrm{p}<0.001 ; * * \mathrm{p}<0.01 ; * \mathrm{p}<0.05$ 
(a)

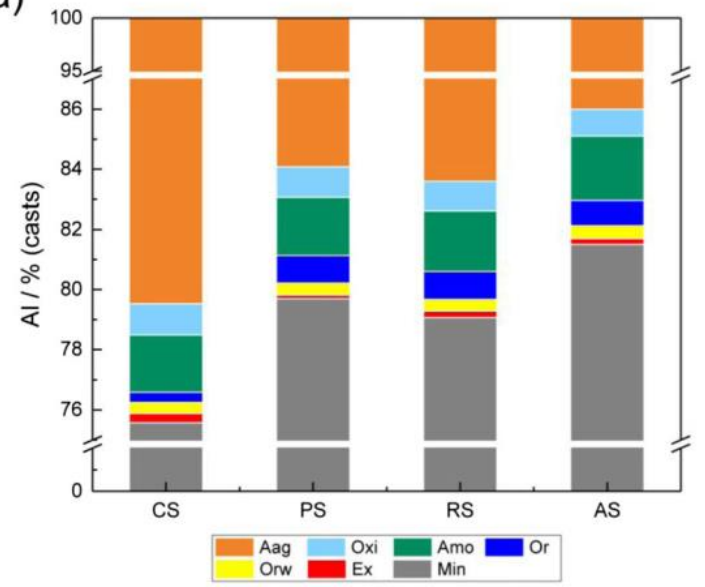

(b)

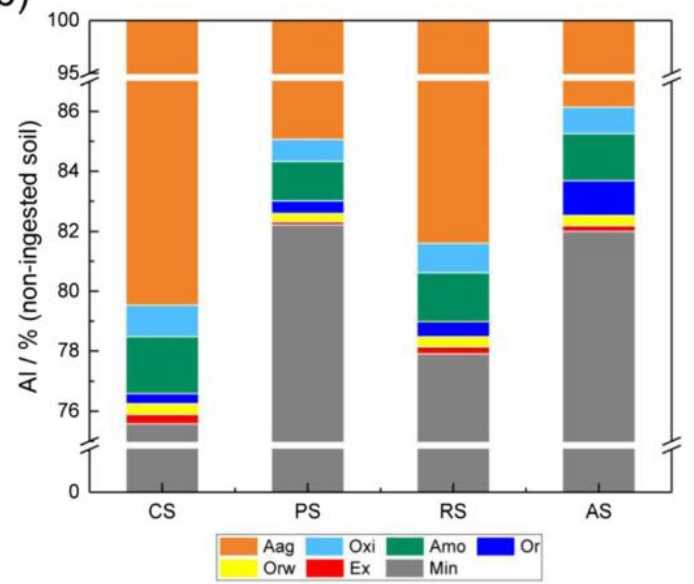

Fig. 3 The percentage of seven fractions of $\mathrm{Al}$ in casts (a) and non-ingested soil (b) of three earthworm species determined by sequential extraction $(\mathrm{n}=5)$

\section{General effects of treatments on Al fractions in casts and non-ingested soils}

PCA was performed to explain the relationship among aluminum fractions, and $\mathrm{pH}$ values of earthworm casts and noningested soil (Fig. 4). Soil Al fractions in casts and noningested soils of three earthworms allowed to identify differences of $\mathrm{Al}$ fractions among the large set of variables observed (Fig. 4a, b). Experiments with casts could be clearly separated from the non-ingested soils along axis 1 that explains $47.7 \%$ of total inertia: casts of P. corethrurus, A. robustus, and A. aspergillum were associated with higher contents of Alorw, Alor, and AlAmo in comparison with the non-ingested soil. The second principal component $(31.9 \%$ of total inertia) indicated differences of earthworm species on $\mathrm{pH}$ value and AlEx and showed that $\mathrm{P}$. corethrurus was more helpful in reducing soil acidification. Results of correlation analysis showed that there was a remarkable correlation respectively between $\mathrm{pH}$ and $\mathrm{Al}_{\mathrm{Ex}}$ in casts $(\mathrm{r}=-0.909 * *)$ and non-ingested soil $(\mathrm{r}=-0.937 * *)$.

\section{Variations of exchangeable base cations, soil $\mathrm{C}, \mathrm{N}$, and $\mathrm{C} / \mathrm{N}$ ratio}

Earthworm addition generally increased the contents of e $\mathrm{x}$ c h a ng e a b l e b a s e c a tions. Theinge s t i o n o $\mathrm{f} P$. corethrurus and A. robustus significantly increased contents of exchangeable $\mathrm{K}\left(\mathrm{K}_{\mathrm{Ex}}\right), \mathrm{Ca}(\mathrm{CaEx})$, and $\mathrm{Mg}$ (MgEx) in casts compared with control soil and noningested soil ( $\mathrm{p}<0.01$, Table 5). The exchangeable $\mathrm{Na}$ (NaEx) contents were significantly higher in casts and noningested soil with addition of $\mathrm{P}$. corethrurus than that in control soil $(p<0.05)$, and the trend was as follows: NaEx contents in non-ingested soil $>$ in casts $>$ control $(\mathrm{p}<$ 0.05). Moreover, CaEx and MgEx contents were significantly higher in casts with addition of A. aspergillum than that in non-ingested soil and control soil $(\mathrm{p}<0.01$, Table 5). Cation exchange capacity (CEC) was significantly higher in the casts of $\mathrm{P}$. corethrurus and $\mathrm{A}$. aspergillum than in control soil as well as non-ingested soils. The highest CEC was observed in the
Fig. 4 Correlation circles of several $\mathrm{Al}$ fractions and $\mathrm{pH}$ characteristics in treatments (a). Projection of experimental points according to treatments (b) casts vs. non-ingested soil. $\mathrm{n}=5$

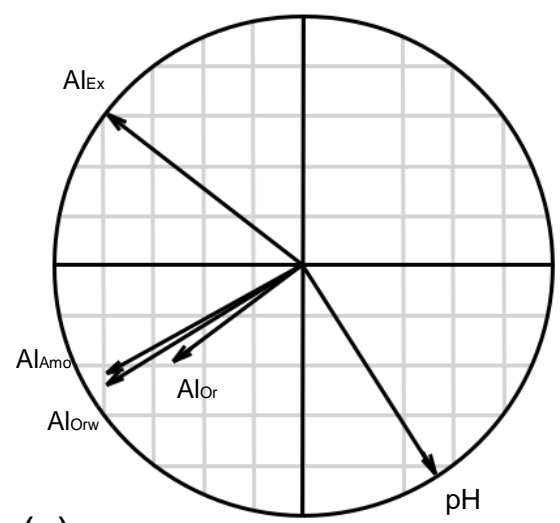

(a)

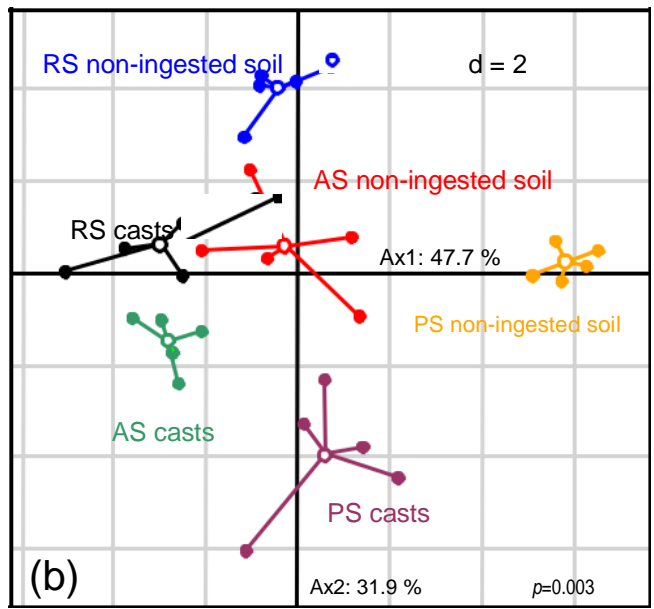




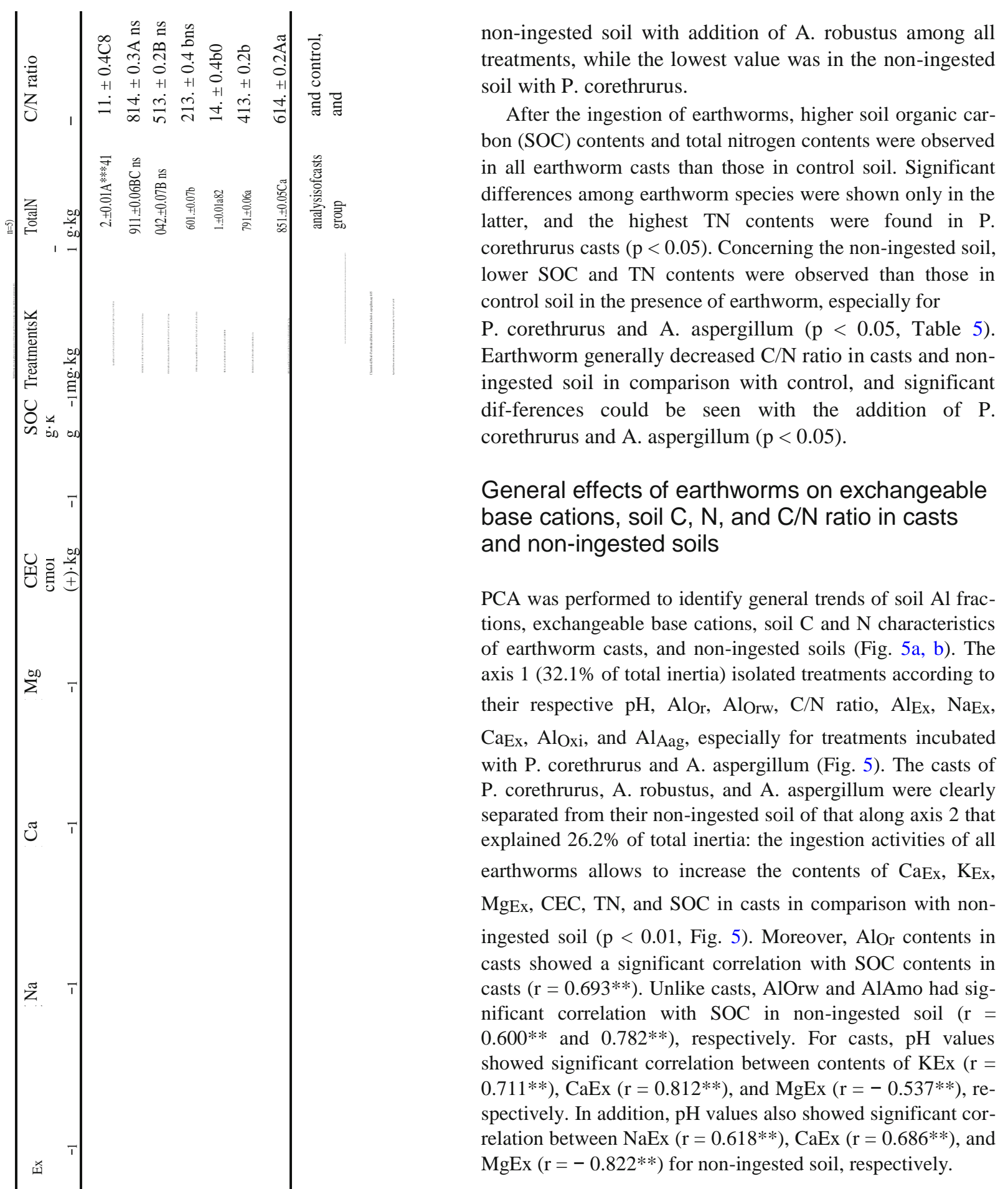

\section{Discussion}

\section{Earthworm growth and $\mathrm{Al}$ accumulation}

It is well known that earthworm density and survival are typically low in acidic soils (Chan and Mead 2003). However, in our study, high survival rates and low biomass loss were observed for the three earthworm species. Some previous studies 
Fig. 5 Projection of soil Al fractions, exchangeable base cations, CEC, $\mathrm{pH}, \mathrm{SOC}, \mathrm{TN}$, and $\mathrm{C} / \mathrm{N}$ ratio in casts and noningested soils in different treatments by PCA. a Correlation cir-cle of variables. b Sore plots in treatment. PS: soil + P. corethrurus; RS: soil + A. robustus; AS: soil + A. aspergillum. $\mathrm{n}=5$
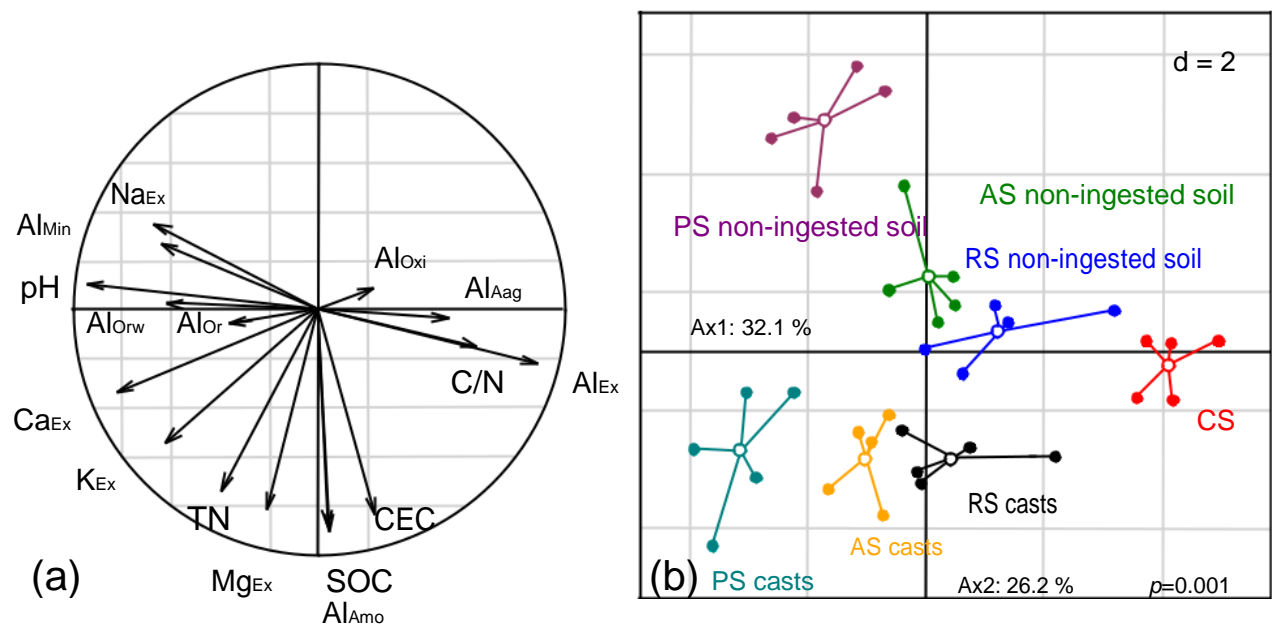

demonstrated that Amynthas sp. and P. corethrurus have out-standing ability to survive in acidic soils $(\mathrm{pH} 3.8)$ (Huang et al. 2015; Shao et al. 2017), and this adaptive advantage may explain the widespread occurrence of these species in south China (Lin et al. 2012).

The cast is the crucial biological aggregate produced by earthworms, which has a positive influence on soil properties (Bossuyt et al. 2005). It was observed that surface soil (0- 20 $\mathrm{cm}$ ) can be all digested by earthworms in 50 years in a tropical forest (Benckiser 1997). In our laboratory culture experiments, endogeic species, especially P. corethrurus, have a higher total cast production than anecic species A. aspergillum (Fig. 1d). Soil ingestion rates of P. corethrurus was similar with that of epi-endogeic species (Amynthas morrisi) in sub-tropical areas (Zhang et al. 2016), about 10fold lower than comparable measurements made for temperate areas endogeic species (Aporrectodea caliginosa) (Zhang et al. 2009) and approximately 80 times lower than that for tropical savanna endogeic species (Millsonia anomala) (Lavelle and Spain 2001). Thus, the cast production of P. corethrurus is higher than that of A. robustus and A. aspergillum, indicating its greater impact on soil properties which is beneficial for soil remediation.

Total Al contents accumulated in the tissues of $\mathrm{P}$. corethrurus, A. robustus, and A. aspergillum were 5933.9, $10,803.9$, and $137.1 \mathrm{mg} \mathrm{kg}^{-1}$ (the corresponding BSAF were $0.087,0.158$ and 0.002 ) in our work, respectively, which suggested that $\mathrm{Al}$ accumulation in earthworms is species dependent. Dai et al. (2004) found that two earthworm species (Aporrectodea caliginosa and Lumbricus rubellus) have different patterns of metal $(\mathrm{Zn}, \mathrm{Cd}$, and $\mathrm{Pb}$ ) bioaccumulation in the same contaminated soil. In detail, the behavioral and ecological characteristics of different earthworms, namely, the food selectivity and the ability to accumulate excess Al, play an important role in their BSAF (Dai et al. 2004). In addition, Zhang et al. (2013) found that the Al content in Eisenia fetida was about $1500 \mathrm{mg} \mathrm{kg}^{-1}$ the acidic soil inoculated with earthworm being collected from the same location as in our work (top $20 \mathrm{~cm}$ latosol), which shows that the earthworm species is the major factor that causes different BSAF in earth-worm. A. robustus is a typical endogeics species that derives its nutrition through consumption of large quantities of min-eral soil, which caused the highest BSAF. As anecic species, A. aspergillum, prefers to feed on the mixture of organic com-pound and soil (Lavelle and Spain 2001); therefore, it has lower accumulation of $\mathrm{Al}$ than A. robustus. The organic inges-tion amount of $P$. corethrurus is between A. robustus and A. aspergillum.

\section{Impacts of earthworm on soil acidification and base cation release}

In acidic forest soils of south China, the addition of earthworms significantly increased soil $\mathrm{pH}$ from 0.41 to 0.79 units (Fig. 2). The highest increase of $\mathrm{pH}$ values in the presence of P. corethrurus confirmed its strong ability to reduce soil acidification in subtropical soil. A similar phenomena was showed in some previous studies (Udovic and Lestan 2007; Wen et al. 2006; Yu et al. 2005), which indicated that this may be due to calciferous glands (García-Montero et al. 2013; Karaca 2011) and the cutaneous mucus secretion, including urine, $\mathrm{NH}_{4}{ }^{+}$, and exchangeable $\mathrm{Ca}^{2+}, \mathrm{Mg}^{2+}$, and $\mathrm{K}^{+}$(Salmon 2001; Sizmur and Hodson 2009). In our work, casts of P. corethrurus and A. aspergillum had significantly higher cation exchange capacity (CEC) than their non-ingested soil $(\mathrm{p}<0.05$, Table 5). Especially significantly higher exchange-able $\mathrm{K}^{+}, \mathrm{Na}^{+}$, and $\mathrm{Ca}^{2+}$ contents of the $\mathrm{P}$. corethrurus casts were observed compared to the control soil (Table 5). It is well known that $\mathrm{pH}$ has an extremely significantly positive corre-lation with exchangeable $\mathrm{Ca}^{2+}$ and $\mathrm{Mg}^{2+}$ (Wang et al. 2018). On one hand, the exchangeable base cation release in earth-worm casts in this study may result in the increase of soil $\mathrm{pH}$ values (Kunito et al. 2016). On the other hand, soil pH in-crease may be due to the secretion of calcium carbonate from 
earthworm calciferous glands (Huang et al. 2015), which may have an important role in regulating the acid-base balance (Briones et al. 2008). Exchangeable $\mathrm{Ca}^{2+}$ and $\mathrm{Mg}^{2+}$ contents and $\mathrm{pH}$ values of all earthworm casts were higher than that of the non-ingested soil ( $p<0.05$, Fig. 2; Table 5) in our study, which indicated that the intestine was the main pathway to release $\mathrm{Ca}^{2+}$ and $\mathrm{Mg}^{2+}$ and intestinal secretions were more effective on soil acidification remediation than skin mucus. Above all, in this work, it was not clear whether soil $\mathrm{pH}$ increase affected by earthworms resulted from the $\mathrm{Ca}^{2+}$ and $\mathrm{Mg}^{2+}$ replacing acid cations on exchange sites or others. A single study may not be sufficient to demonstrate these effects.

\section{Impacts of earthworm on Al fractions}

In general, according to PCA analysis (Figs. 4 and 5), earth-worm modified $\mathrm{Al}$ fractions in the soils and transferred $\mathrm{Al}$ from the exchangeable fraction to the residual fraction and the fraction bound to organic matter and thus reduced the bio-toxicity of $\mathrm{Al}$ in our study. This phenomenon may be due to the change of $\mathrm{pH}$ and the availability of cations (Sizmur and Hodson 2009) and their ingestion on soil organic matter (Zhang et al. 2016). Considering earthworms were col-lected in the same site as the soil, there would be no net loss of $\mathrm{Al}$ after worms were taken away although P. corethrurus, A. robustus, and A. aspergillum can accumulate $\mathrm{Al}$ in their bodies. Significant negative relationship between $\mathrm{pH}$ and $\mathrm{Al}_{\mathrm{Ex}}$ in our study (Fig. 4) confirmed the positive effect of soil acidification on the increase of soil-exchangeable Al (Bailey et al. 2005). Exchangeable $\mathrm{Al}\left[\mathrm{Al}^{3+}, \mathrm{AlOH}^{2+}, \mathrm{Al}(\mathrm{OH}) 2^{+}\right.$, $\mathrm{Al}(\mathrm{OH})_{3}$, and $\left.\mathrm{Al}(\mathrm{OH})_{4}\right]$ contents represent an essential factor for soil potential acid-producing capacity in subtropical soil, which is deleterious to soil organisms (Kunito et al. 2016; Baquy et al. 2018). Lower $\mathrm{Al}_{\mathrm{Ex}}$ contents in the presence of earthworm confirmed earthworm effects on decreasing soil Al toxicity in subtropical soil. AlOrw, $\mathrm{AlOr}$, and $\mathrm{Al}_{\mathrm{Amo}}$ are always regarded as potentially reactive $\mathrm{Al}$ pool in acidic soil (Jou and Kamprath 1979) and strongly influenced by soil organic mat-ter (Pierart et al. 2018; Shao et al. 1998). It is generally thought that most of the Al bounded to organic matter in the soil is of low toxicity (Buodot et al. 1994). Al extracted by acid ammo-nium oxalate $\left(\mathrm{Al}_{\mathrm{Amo}}\right)$ provides an estimate of the non-crystalline $\mathrm{Al}$ (Álvarez et al. 2012). AlOxi, $\mathrm{Al}_{\mathrm{Aag}}$, and $\mathrm{Al}_{\text {Min }}$ are usually considered as the relatively stable species (Shao et al. 1998). In the presence of three earthworms, moreover in our study, the increase of the $\mathrm{Al}_{\text {Orw }}, \mathrm{Al}_{\mathrm{Or}}$, and $\mathrm{Al}_{\mathrm{Amo}}$ contents in all earthworm casts may be due to the higher SOM contents in casts resulting in a strong affinity between organic matters and $\mathrm{Al}$ ( $\mathrm{Li}$ et al. 2006), as the positive relationship between $\mathrm{Al}_{\mathrm{Amo}}$ and $\mathrm{SOM}$ contents is shown in Fig. 5. Therefore, just like other metal(loid)s, such as $\mathrm{Cd}, \mathrm{Cu}$, $\mathrm{Zn}$, and As, earth-worms may regulate the content of Alorw, Alor, and $\mathrm{Al}_{\mathrm{Amo}}$ in casts by affecting the degradation and redistribution of soil organic matter (Tica et al. 2013).

Higher AlEx, AlOrw, AlOr, and $\mathrm{Al}_{\mathrm{Amo}}$ in earthworm casts than non-ingested soil may indicate that $\mathrm{Al}$ metabolization from the gut is the main route instead of skin mucus (Table 4). Moreover, Al fractions affected by earthworm may be species dependent. A. aspergillum, as anecic species, may secrete special mucus resulting in the increased contents of Alor in non-ingested soil compared to casts (Table 4). In addition, different ecological earthworm species differ in their feeding preference for soil organic matter (Lavelle and Spain 2001). In our study, P. corethrurus may prefer soil particles with higher organic matter content than $\mathrm{A}$. robustus and se-cretes more exchangeable $\mathrm{K}^{+}$and $\mathrm{Ca}^{2+}$ contents in guts (Fig. 5), which results in their stronger effect on the decrease of AlEx contents and the increase of stable fractions (Table 4; Figs. 3 and 4) than for other earthworm species. Further study should be conducted on earthworm physiological characteris-tics, such as calciferous glands, the composition of intestinal secretions and skin mucus, owning to their great effect on $\mathrm{Al}$ fractions.

\section{Conclusions}

Our study demonstrated that P. corethrurus, A. robustus, and A. aspergillum have different impacts on soil acidification, $\mathrm{Al}$ fractions, and base cation release in a south China subtropical soil. Firstly, three earthworms, especially P. corethrurus, significantly reduced soil acidification. Subsequently, the increases of $\mathrm{pH}$ values in casts and non-ingested soil may be due to the release of exchangeable cation from their intestinal secretions and mucus. The intestine may be the main pathway for the release of $\mathrm{Ca}^{2+}$ and $\mathrm{Mg}^{2+}$. Finally, all three earthworms altered $\mathrm{Al}$ fractions and reduced $\mathrm{Al}$ toxicity, especially P. corethrurus which decreased $61.7 \%$ of exchangeable Al contents in cast compared to control soil while increasing the contents of AlOrw, $\mathrm{Al}_{\text {Or, }}$ and $\mathrm{Al}_{\mathrm{Amo} \text {. }}$

Acknowledgements Thanks to Qijun Yang, Haoyu Wang, and Huan Qian for laboratory assistance.

Funding information This research was supported by the Natural Science Foundation of China (Grant No. 41201305 and 41601227) and National Key Research and Development Program of China (2016YFD0201301 and 2016YFD0201200).

\section{References}

Álvarez E, Fernández-Sanjurjo MJ, Núñez A, Seco N, Corti G (2012) Aluminium fractionation and speciation in bulk and rhizosphere of a grass soil amended with mussel shells or lime. Geoderma 173-174: 322-329 
Bailey SW, Horsley SB, Long RP (2005) Thirty years of change in forest soils of the Allegheny plateau, Pennsylvania. Soil Sci Soc Am J 69: 681-690

Baquy AA, Li JY, Jiang J, Mehmood K, Shi RY, Xu RK (2018) Critical $\mathrm{pH}$ and exchangeable $\mathrm{Al}$ of four acidic soils derived from different parent materials for maize crops. J Soils Sediments 18:1490-1499 Basker A, Kirkman JH, Macgregor AN (1994) Changes in potassium availability and other soil properties due to soil ingestion by earthworms. Biol Fertil Soils 17:154-157

Benckiser G (1997) Fauna in soil ecosystems recycling processes, nutri-ent fluxes, and agricultural production. Marcel Dekker. Madison, New York, pp 173-225

Blouin M, Hodson ME, Delgado EA, Baker G, Brussaard L, Butt KR, Dai J, Dendooven L, Peres G, Tondoh JE, Cluzeau D, Brun JJ (2013) A review of earthworm impact on soil function and ecosys-tem services. Eur J Soil Sci 64:161-182

Bossuyt H, Six J, Hendrix PF (2005) Protection of soil carbon by microaggregates within earthworm casts. Soil Biol Biochem 37: 251-258

Briones MJI, Ostle NJ, Piearce TG (2008) Stable isotopes reveal that the calciferous gland of earthworms is a $\mathrm{CO}_{2}$-fixing organ. Soil Biol Biochem 40:554-557

Chan KY, Mead JA (2003) Soil acidity limits colonisation by Aporrectodea trapezoides, an exotic earthworm. Pedobiologia 47: $225-229$

Cortet J, Vauflery AGD, Balaguer NP, Gomot L, Texier C, Cluzeau $D$ (1999) The use of invertebrate soil fauna in monitoring pollutant effects. Eur J Soil Biol 35:115-134

Dai J, Becquer T, Rouiller JH, Reversat G, Bernhard-Reversat F, Nahmani J, Lavelle P (2004) Heavy metal accumulation by two earthworm species and its relationship to total and DTPAextractable metals in soils. Soil Biol Biochem 36:91-98

Evans AJR, Jacobs MB (2016) Aluminum activity in alpine tundra soil, Rocky Mountain National Park, Colorado, U.S.A. Soil Sci 181: 359-367

García-Montero LG, Valverde-Asenjo I, Grande-Ortíz MA, Menta C, Hernando I (2013) Impact of earthworm casts on soil pH and calcium carbonate in black truffle burns. Agrofor Syst 87:815-826

Gestel VCAM, Hoogerwerf G (2001) Influence of soil pH on the toxicity of aluminium for Eisenia andrei (Oligochaeta: Lumbricidae) in an artificial soil substrate. Pedobiologia 45:385-395

Guo JH, Liu XJ, Zhang Y, Shen JL, Han WX, Zhang WF, Christie P, Goulding KWT, Vitousek PM, Zhang FS (2010) Significant acidification in major Chinese croplands. Science 327:1008-1010

Hagvall K, Persson P, Karlsson T (2015) Speciation of aluminum in soils and stream waters: the importance of organic matter. Chem Geol 417:32-43

Hodson ME, Donner E (2013) Managing adverse soil chemical environ-ments. In: Gregory PJ, Nortcliff S (eds) Soil conditions and plant growth. Blackwell, Chichester, pp 195-237

Huang JH, Zhang WX, Liu MY, Briones MJI, Eisenhauer N, Shao YH, Cai XA, Fu SL, Xia HP (2015) Different impacts of native and exotic earthworms on rhizodeposit carbon sequestration in a sub-tropical soil. Soil Biol Biochem 90:152-160

Jou ASR, Kamprath EJ (1979) Copper chloride as an extractant for esti-mating the potentially reactive aluminum pool in acid soils. Soil Sci Soc Am J 43:35-38

Karaca A (2011) Biology of earthworms. Chapman \& Hall, London, pp 51-67

Kubová J, Matúš P, Bujdoš M, Medved J (2005) Influence of acid mining activity on release of aluminum to the environment. Anal Chim Acta 547:119-125

Kunito T, Isomura I, Sumi H, Park HD, Toda H, Otsuka S, Nagaoka K, Saeki K, Senoo K (2016) Aluminum and acidity suppress micro-bial activity and biomass in acidic forest soils. Soil Biol Biochem 97:23-30
Larssen T, Vogt RD, Seip HM, Furuberg G, Liao JS, Xiong JL (1999) Mechanisms for aluminum release in Chinese acid forest soils. Geoderma 91:65-86

Lavelle P, Spain AV (2001) Soil ecology. Kluwer Scientific Publications, Dordrecht, pp 288-298

Li JY, Xu RK, Tiwari D, Ji GL (2006) Mechanism of aluminum release from variable charge soils induced by low-molecularweight organic acids: kinetic study. Geoderma 70:2755-2764

Lin Z, Li XM, Li YT, Huang DY, Dong J, Li FB (2012) Enhancement effect of two ecological earthworm species (Eisenia foetida and Amynthas robustus E. Perrier) on removal and degradation processes of soil DDT. J Environ Monit 14:1551-1558

Moro H, Kunito T, Saito T, Yaguchi N, Sato T (2014) Soil microorgan-isms are less susceptible than crop plants to potassium deficiency. Arch Agron Soil Sci 60:1807-1813

Müller F (1857) Lumbricus corethrurus. Burstenschwanz. Archiv Fur Naturg 23: 6-113

Perrier E (1872) Lombriciens Terrestres. Nouvelles Archives Du Museum. 4-192

Pierart A, Dumat C, Maes AQ, Roux C, Sejalon-Delmas N (2018) Opportunities and risks of biofertilization for leek production in urban areas: influence on both fungal diversity and human bioaccessibility of inorganic pollutants. Sci Total Environ 624:1140-1151

Qiao X, Xiao WY, Jaffe D, Kota SH, Ying Q, Tang Y (2015) Atmospheric wet deposition of sulfur and nitrogen in Jiuzhaigou National Nature Reserve, Sichuan Province, China. Sci Total Environ 511:28-36

R Development Core Team (2007) R: a language and environment for statistical computing, Vienna, Austria. (ISBN 3-900051-070). http://www.R-project.org

Richardson JB, Blossey B, Dobson AM (2018) Earthworm impacts on trace metal $(\mathrm{Al}, \mathrm{Fe}, \mathrm{Mo}, \mathrm{Cu}, \mathrm{Zn}, \mathrm{Pb})$ exchangeability and uptake by young Acer saccharum and Polystichum acrostichoides. Biogeochemistry 138:103-119

Salmon S (2001) Earthworm excreta (mucus and urine) affect the distribution of springtails in forest soils. Biol Fertil Soils 34:304-310

Shao ZC, He Q, Wang WJ (1998) Forms of aluminum in red soils. Acta Pedol Sin 35:38-48 (in Chinese with English abstract)

Shao YH, Zhang WX, Eisenhauer N, Liu T, Xiong YM, Liang CF, Fu SL (2017) Nitrogen deposition cancels out exotic earthworm effects on plant-feeding nematode communities. J Anim Ecol 86:708-717

Sizmur T, Hodson ME (2009) Do earthworms impact metal mobility and availability in soil? - a review. Environ Pollut 157:1981-1989

Sizmur T, Palumbo-Roe B, Hodson ME (2011) Impact of earthworms on trace element solubility in contaminated mine soils amended with green waste compost. Environ Pollut 159:1852-1860

SSIR (2004) Soil survey laboratory methods manual, soil survey investi-gations report, version 4.0 ed. United States Department of Agriculture, USA, pp 173-177

Ščančar J, Milačič R (2006) Aluminium speciation in environmental samples: a review. Anal Bioanal Chem 386:999-1012

Thioulouse J, Chessel D, Dolédec S, Olivier JM (1997) ADE-4: a mul-tivariate analysis and graphical display software. Stat Comput 7: 75-83

Tica D, Udovic M, Lestan D (2013) Long-term efficiency of soil stabilization with apatite and Slovakite: the impact of two earthworm species (Lumbricus terrestris and Dendrobaena veneta) on lead bioaccessibility and soil functioning. Chemosphere 91:1-6

Udovic M, Lestan D (2007) The effect of earthworms on the fractionation and bioavailability of heavy metals before and after soil remediation. Environ Pollut 148:663-668

Wang AQ, Lin K, Ma CX, Gao Q, Zhu QF, Ji XJ, Zhang G, Xue L, Zu CL, Jiang CQ, Shen J, Li DC (2018) A brief study on pH, exchangeable $\mathrm{Ca}^{2+}$ and $\mathrm{Mg}^{2+}$ in farmlands under tobacco-rice rotation in Xuancheng city of South Anhui. Agric Sci 9:480-488 
Wen B, Liu Y, Hu XY, Shan XQ (2006) Effect of earthworms (Eisenia fetida) on the fractionation and bioavailability of rare earth elements in nine Chinese soils. Chemosphere 63:1179-1186

Xu RK (2012) Amelioration principles and technologies for acidified red soils. Science Press, Beijing, pp 1-6

Yu XZ, Cheng JM, Wong MH (2005) Earthworm-mycorrhiza interac-tion on $\mathrm{Cd}$ uptake and growth of ryegrass. Soil Biol Biochem 37: 195-201

Zhang BG, Li GT, Shen TS, Wang JK, Sun Z (2000) Changes in micro-bial biomass $\mathrm{C}, \mathrm{N}$, and $\mathrm{P}$ and enzyme activities in soil incubated with the earthworms Metaphire guillelmi or Eisenia fetida. Soil Biol Biochem 32:2055-2062

Zhang C, Langlest R, Velasquez E, Pando A, Brunet D, Dai J, Lavelle P (2009) Cast production and NIR spectral signatures of Aporrectodea caliginosa fed soil with different amounts of halfdecomposed Populus nigra litter. Biol Fertil Soils 45:839-844
Zhang JE, Yu JY, Ouyang Y, Xu HQ (2013) Responses of earthworm to aluminum toxicity in latosol. Environ Sci Pollut Res 20:1135-1141

Zhang C, Mora P, Dai J, Chen XF, Giusti-Miller S, Ruiz-Camacho N, Velasquez E, Lavelle P (2016) Earthworm and organic amendment effects on microbial activities and metal availability in a contaminated soil from China. Appl Soil Ecol 104:54-66

Zhao Y, Duan L, Xing J, Larssen T, Nielsen PC, Hao JM (2009) Soil acidification in China: is controlling $\mathrm{SO}_{2}$ emissions enough? Environ Sci Technol 43:8021-8026 